\title{
Notes on the bionomy of two spider wasp species in an urban forest fragment in Brazil
}

\author{
Diego Marinho, ${ }^{1,2}$ \& Felipe Vivallo, ${ }^{1,3}$ \\ 1 Universidade Federal do Rio de Janeiro (UFRJ), Museu Nacional (MN), Departamento de Entomologia, \\ Programa de Pós-Graduação em Zoologia. Rio de Janeiro, RJ, Brasil. \\ ${ }^{2}$ ORCID: http://orcid.org/0000-0001-5319-0432.E-mail: diego.mp89@gmail.com \\ 3 ORCID: http://orcid.org/0000-0002-4487-0804. E-mail: fvivallo@yahoo.com
}

\begin{abstract}
There are few studies dedicated to the natural history of Neotropical spider wasps (Pompilidae). When it comes to urban areas, the knowledge on these wasps is even scarcer. This study sheds light on the natural history of Auplopus cf. rufipes and $A$. cf. brasiliensis (Hymenoptera: Pompilidae: Ageniellini) from an urban Atlantic Forest fragment in the Jardim Botânico do Rio de Janeiro, Rio de Janeiro City, Brazil. Auplopus cf. rufipes displays a multivoltine pattern and frequently nests in bamboo canes scattered in the open areas, whereas $A$. cf. brasiliensis is a rare sight, with only a single nest collected from a hose trapnest. Females of the former species show aggressive behaviour, which suggests a solitary lifestyle. Their nests were partly enveloped in a complex structure, similar to other species that build free-standing, unconcealed nests and display some degree of sociality. Such behaviour could not be observed for $A$. cf. brasiliensis. Despite that, nests of both species were built using mud pellets, though the brood cells differed regarding arrangement and position in the trap. Two parasites were found attacking the cells: Caenochrysis crotonis (Chrysididae) in a cell of $A$. cf. rufipes, and Chaenotetrastichus neotropicalis (Eulophidae) in two cells of $A$. cf. brasiliensis, both recorded for the first time. Auplopus cf. rufipes was found to prey on Frigga cf. quintensis (Salticidae), the first record of this genus as a host of Auplopus.
\end{abstract}

Key-Words. Ageniellini; Auplopodina; Auplopus; Nesting; Atlantic Forest.

\section{INTRODUCTION}

The pompilid wasps (Pompilidae) are cosmopolitan and most species are spider parasitoids, although some genera are known to be cleptoparasites of other pompilids as well. It is a highly diverse group comprising approximately 4,855 species worldwide (Aguiar et al., 2013), which challenges systematists (Waichert et al., 2015) and still lacks comprehensive studies on their biology.

Ageniellini presents several derived traits regarding nesting biology within Pompilidae (Shimizu et al., 2010). For instance, the species of this tribe nest above the ground, using a variety of sheltered locations, and build their nest prior to finding a host. In this tribe, the genus Auplopus (Auplopodina) is largely distributed throughout the Neotropical region and its species are known for building their nests using mainly mud (Wcislo et al., 1988; Dos Santos et al., 2017). This and other genera of Ageniellini, display levels of social behaviour, which is related with the nesting dynamic (Shimizu et al., 2010).

It is interesting to point out the importance of these data in the context of urban cities, especially regarding the rearing and management of these key organisms for the sake of ecosystemic functions. Wasps are very important control agents of several arthropod populations, like insects and spiders. We still need to fully understand how these interactions are taking place in biomes that have been ravaged by human activity such as the Atlantic Forest. Unfortunately, little data is available for these organisms, especially for wasps like the Pompilidae (Zanette et al., 2004; Buschini et al., 2007; Waichert \& Pitts, 2012). This study represents a step towards filling this gap, presenting data on the natural history of Auplopus cf. rufipes and, to a lesser extent, $A$. cf. brasiliensis, from an urban forest fragment in the city of Rio de Janeiro, Brazil.

\section{MATERIAL AND METHODS}

Nesting activities of females were observed at the Jardim Botânico do Rio de Janeiro (22 $2^{\circ} 8^{\prime} 14^{\prime \prime}$, $43^{\circ} 13^{\prime} 18^{\prime \prime} \mathrm{W}$ ) (JBRJ henceforth). The JBRJ is an urban forest fragment that belongs to the Atlantic Forest biome, and is located in the city of Rio de Janeiro, Brazil. It comprises two main areas: the arboretum, which has several native and exotic 
plant species; and a forest matrix contiguous with Parque Nacional da Tijuca and Parque da Cidade, two relatively well preserved fragments of the Atlantic Forest.

Trap-nests (referred to as traps, from now on) made of bamboo cane and hoses were placed in five transects, each of them with five spots approximately $125 \mathrm{~m}$ apart, to a total of 25 sample units in the area. Each sample unit had 30 traps, 15 bamboo cane traps (with diameters ranging from $0.4 \mathrm{~cm}$ to $2.4 \mathrm{~cm}$ ) and 15 hose traps (split into three diameter categories of $0.79 \mathrm{~cm}, 0.95 \mathrm{~cm}$ and $1.27 \mathrm{~cm}$ - with five of each). Additionally, 96 traps made of plastic straw with $0.5 \mathrm{~cm}$ of diameter were set in three localities in the JBRJ, the forest matrix, the middle of the arboretum and the outermost point in the area, near the end of the park.

When the nests were built to completion, they were taken to the Laboratório de Hymenoptera of the Museu Nacional of Rio de Janeiro (HYMN), and replaced by empty traps of the same diameter. Nests were maintained in the laboratory with organza fabric attached to its open end, fastened with rubber string to stop emerging adults from leaving the nest. A single nest collected in September 2017 was opened to identify the hosts stored in the brood cells.

Images were recorded using a Leica DFC450 camera attached to a Leica M205C stereomicroscope and using the extended-focus software Leica Application Suite v4.8.0. Image stacking was performed by Combine ZP

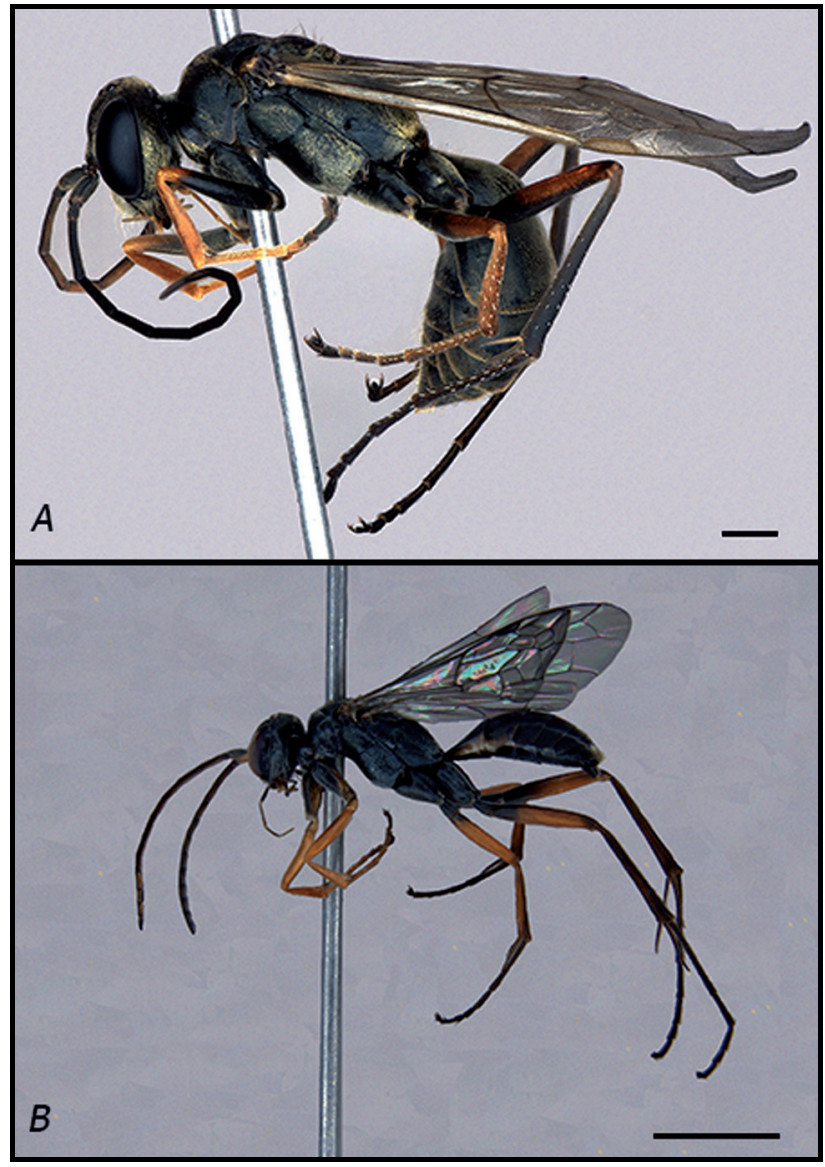

Figure 1. (A) Female of Auplopus cf. rufipes. Scale bar $=1 \mathrm{~mm}$. (B) Male of Auplopus cf. brasiliensis. Scale bar $=3 \mathrm{~mm}$. v.7.0.0.1 software. Voucher specimens (Fig. 1) are deposited in the entomological collections of Museu Nacional/ Universidade Federal do Rio de Janeiro and Universidade Vila Velha, Espírito Santo, Brazil.

\section{RESULTS}

\section{Auplopus cf. rufipes}

Nests of this species were sparsely collected in the studied area. They were built in bamboo cane traps that ranged from 12 to $16 \mathrm{~mm}$ in diameter and were approximately $15 \mathrm{~cm}$ long. Five nests were collected between April/2017 and February/2019 (Table 1). The nest collected in April/2017 spawned two specimens, a male

Table 1. Nests of species of Auplopus collected at the Jardim Botânico do Rio de Janeiro, Brazil. $\emptyset=$ diameter; $\sigma^{\top}=$ male; $\$=$ female; $-=$ data unavailable.

\begin{tabular}{cccccc}
\hline \multicolumn{1}{c}{ Species } & Nest( $(\mathbf{)}$ & Month-Year & Brood cell number & $\sigma^{\text {x:O }}$ & Mortality \\
\hline Auplopus cf. rufipes & $1(12)$ & Apr-17 & 2 & $1: 1$ & 0 \\
& $2(12)$ & May-17 & 3 & - & - \\
& $3(13)$ & May-17 & 2 & - & - \\
& $4(16)$ & Sep-17 & 6 & $3: 1$ & 2 \\
& $5(16)$ & Nov-18 & 6 & $2: 0$ & 4 \\
\hline Auplopus cf. brasiliensis & $1(12.7)$ & Jul-17 & 3 & $1: 0$ & 2 \\
\hline
\end{tabular}

Table 2. Nests collected and spawning of adults at the Jardim Botânico do Rio de Janeiro. Nests 2 and 3 of Auplopus cf. rufipes lack information because of the fire that hit the Museu Nacional on September $3^{\text {rd }}, 2018$. The immatures were diapausing by the time the Museu Nacional suffered the fire accident, so that their mortality was displayed as unknown.

\begin{tabular}{|c|c|c|c|c|c|}
\hline & Nest & Nest building & Nest collected & Emergence & Sex \\
\hline \multirow[t]{9}{*}{ Auplopus cf. rufipes } & 1 & April 3, 2017 & April 18, 2017 & May 12, 2017 & M \\
\hline & & & & May 15, 2017 & $\mathrm{~F}$ \\
\hline & 2 & May 4, 2017 & May 19, 2017 & - & - \\
\hline & 3 & May 4, 2017 & May 19, 2017 & - & - \\
\hline & 4 & Aug 19, 2017 & Sep 21, 2017 & Oct 11, 2017 & M \\
\hline & & & & Oct 11, 2017 & M \\
\hline & & & & Oct 12, 2017 & M \\
\hline & & & & Oct 13, 2017 & $\mathrm{~F}$ \\
\hline & 5 & 0ct 20,2018 & Nov 16, 2018 & Nov 21, 2017 & M \\
\hline Caenochrysis crotonis & 5 & 0 ct 20,2018 & Nov 16, 2018 & Oct 23, 2018 & M \\
\hline Auplopus cf. brasiliensis & 1 & May 4, 2017 & May 19, 2017 & Jul 10, 2017 & M \\
\hline Chaenotetrasticus neotropicalis & 1 & May 4, 2017 & May 19, 2017 & Jul 27, 2017 & $\mathrm{~F}$ \\
\hline
\end{tabular}

Table 3. Brood cells measures taken from nests of species of Auplopus at the Jardim Botânico do Rio de Janeiro, Brazil. The nest collected in September/2017 lacks (4 and C5 values, because they were broken during handling. $C=$ brood cell. The brood cells counting is made from the most inner cell (C1) to the most outer cell (the last one built). Measurements are displayed in millimetres.

\begin{tabular}{lccccccc}
\hline \multicolumn{1}{c}{ Species } & Month-Year & C1 & C2 & C3 & C4 & C5 & C6 \\
\hline Auplopus cf. rufipes & apr-17 & 13.44 & 10.58 & - & - & - & - \\
& sep-17 & 15.59 & 16.28 & 15.23 & - & - & 18.67 \\
& nov-18 & 17.76 & 16.86 & 15.12 & 14.80 & 16.83 & 16.35 \\
\hline Auplopus cf. brasiliensis & jul-17 & 8.34 & 12.01 & 10.08 & - & - & - \\
\hline
\end{tabular}


and a female; from the nests collected in May/2017 all wasps died in the pupal stage. From the nests collected in September/2017, three males and a female emerged 20 days after retrieval from the field (Tables 1 and 2). Additionally, one larva died due to handling and another one for unknown reasons. In 2018, only one nest was collected in November, from which emerged one male and a specimen of cuckoo wasp Caenochrysis crotonis (Ducke) (Hymenoptera: Chrysididae) emerged. Other four immatures died from unknown causes.

Direct observations of female nesting activities were frustrated given their aggressive behaviour whenever attempts to record the foundress activity closely were made, causing them to stop working on the nests. In such events, the females would face the unwelcome observer, flapping their wings against the trap floor and extending their metasoma, as if preparing to sting. This menacing posture behaviour was only witnessed twice, since the observed nests were unattended most of the time. Prey carrying behaviour, unfortunately, could not be seen.

The nests of this species were made of mud. Moist mud droplets were stacked, creating a papillated outer surface for the nest cells. After some time, the mud dried and became cemented. Measurements for brood cells are summarised in Table 3. Most nests were built near the bottom of the trap, except for one that was built detached from the trap bottom by about $4 \mathrm{~mm}$, leaving a small empty space. The first cells were built sequentially, occupying only half of the trap's width. As the nest grew, other brood cells were added next to the first row, occupying the remaining space. Nests with more than two cells show a typical " $V$ " formation when seen from above (Fig. 2A). The second set of nests, embedded between the first ones, had their entrances directed upward, filling all the space. When the two halves of the trap were separated, part of the mud that formed the nest was adhered to its superior half. In addition, the cells were tightly glued together, in a way that the entire nest may be removed from the trap.

Empty spaces of the nests were covered by one layer of mud, which partially enveloped all the brood cells (Fig. 2B) creating an overlay. Although most of the exposed surface of each brood cell was papillated (Fig. 2C), the regions in contact with the trap walls or other brood cells were smooth (Fig. 2D). The inner surface of each brood cell was smooth, with almost no wrinkle. Brood cells were cylindric-oblong and they were tilted about $80^{\circ}$ related to the substrate (Fig. $2 \mathrm{~B}$ ). Unfinished cells had a structure binding the entrance orifice, similar to a "lip" (Fig. 2C). Brood cells colour was uniform.

One of the nests collected was opened to identify the prey hunted by the foundress wasp. All spiders stocked as food for the larvae belonged to the species Frigga cf. quintensis (Tullgren) (Salticidae). Six cells were analysed which contained two males, three females and a juvenile, which could not be sexed. Figure 3 depicts the different

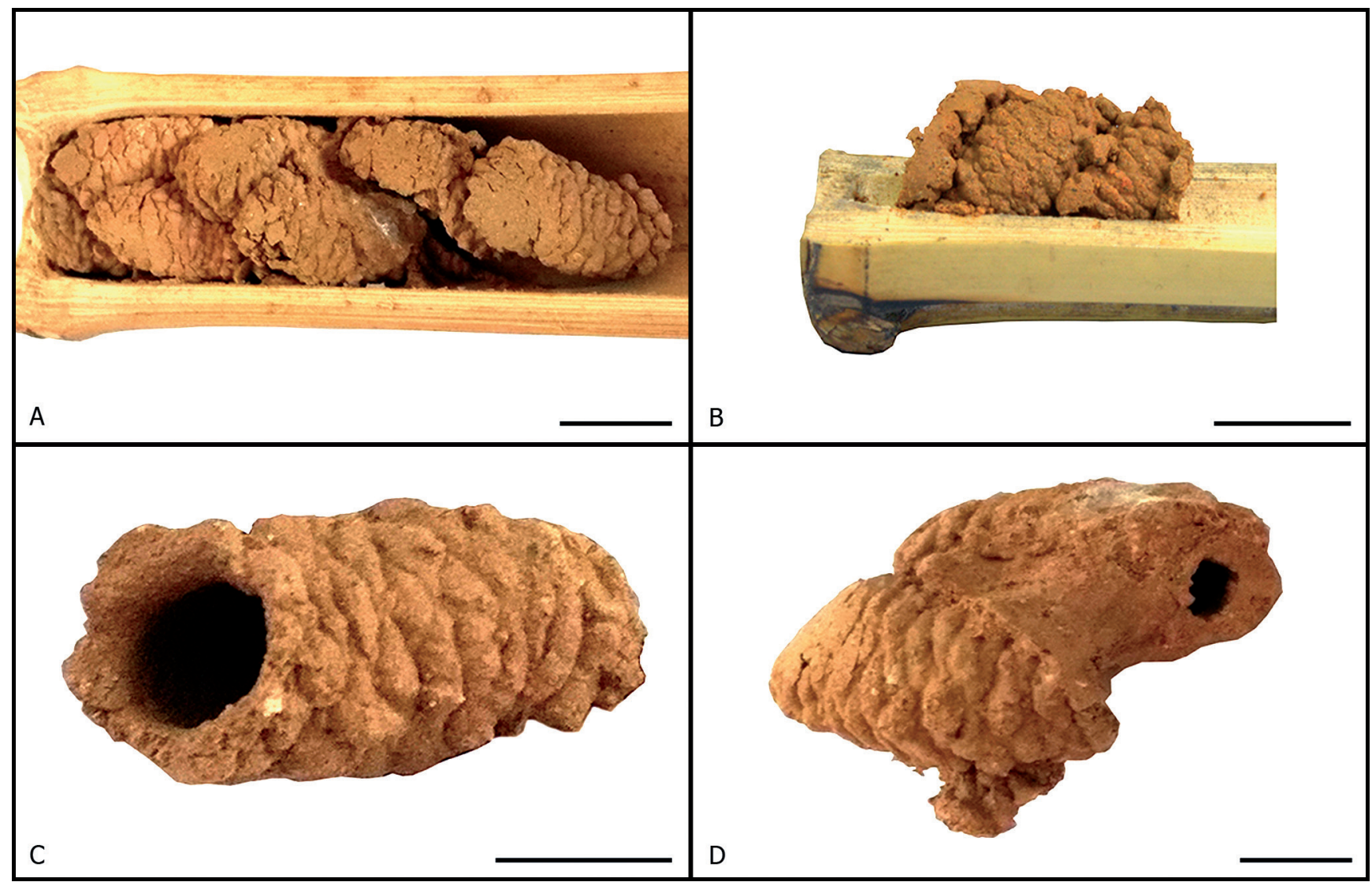

Figure 2. Nest of Auplopus cf. rufipes. (A) Arrangement of cells inside the trap nest. Scale bar $=1 \mathrm{~cm}$. (B) Nest in profile showing an overlay on the first cell and the cells leaning. Scale bar $=1 \mathrm{~cm}$. (C) Cell lip-shaped structure before provision. Scale bar $=0.5 \mathrm{~cm}$. (D) Brood cells glued together, one of them with an emergence hole. Scale bar $=0.5 \mathrm{~cm}$. 
stages of the immatures from the innermost (Fig. 3A) to the outermost cell (Fig. 3F) of the opened nest. The spiders were placed with their abdomen facing the posterior part of the brood cell, the cephalothorax facing the opening of the cell, and only the posterior-most pair of legs were amputated near the coxa-trochanter joint (Fig. 3C). The egg was laid on the ventral surface of the spider's opisthosoma, dislocated to the right (Figs. 3D-F). The larva started to feed in the region where the egg was laid, sucking the prey's internal fluids. Upon reaching the third instar, the larva consumed the prey entirely and, after the fourth instar, it pupated, but did not spin a cocoon. Subsequently, the adult emerged by chewing through the cell operculum, making a small hole.

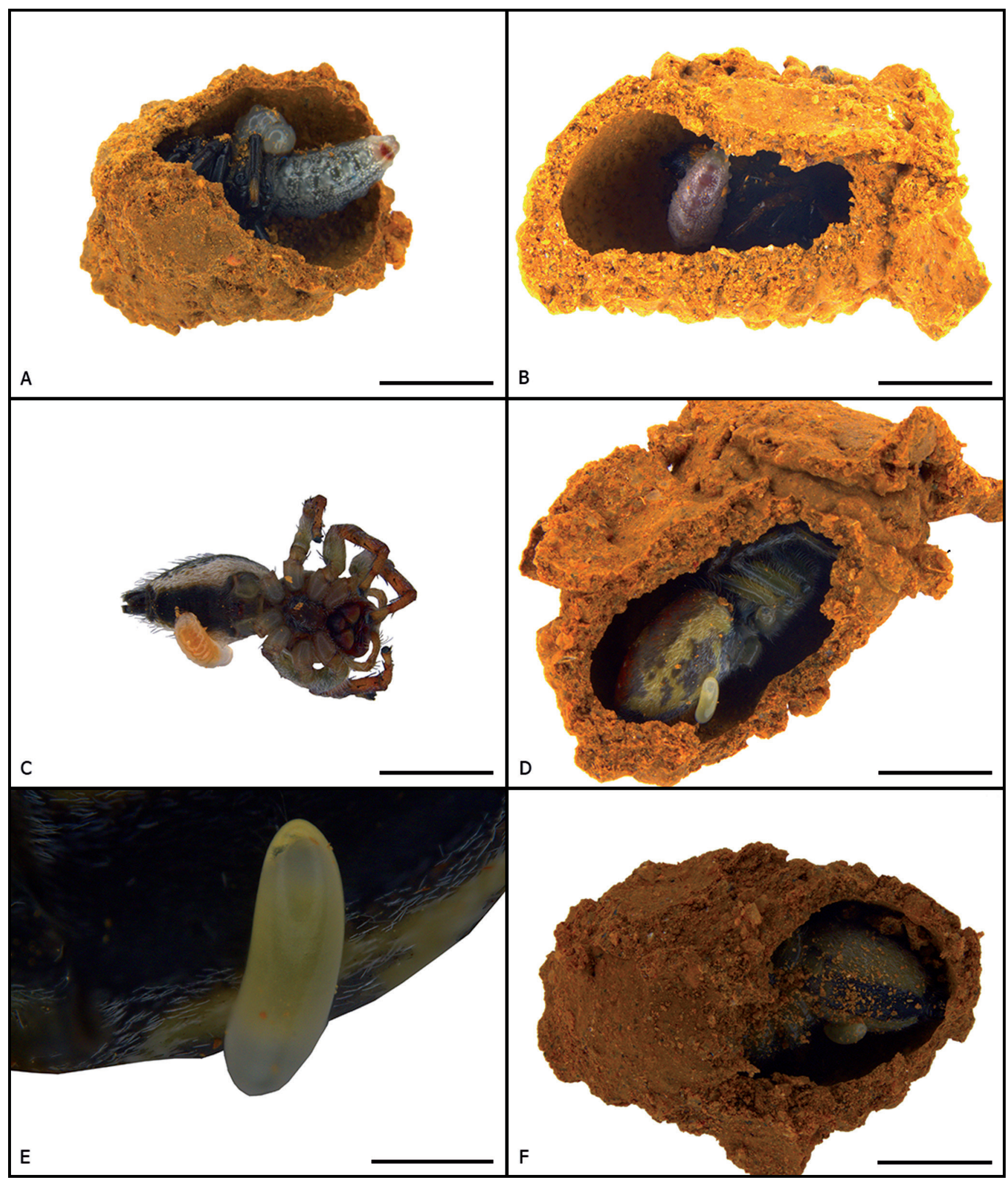

Figure 3. Development stages of Auplopus cf. rufipes. (A) Larva almost entirely developed feeding on a spider. Scale bar $=0.5 \mathrm{~cm}$. (B) Larva probably in its third instar feeding. Scale bar $=0.5 \mathrm{~cm}$. (C) Second instar larva. Scale bar $=0.5 \mathrm{~cm}$. (D) Prey tightly trapped in the brood cell and egg placed on its opistosoma. Scale bar $=0.5 \mathrm{~cm}$. (E) Egg in detail. Scale bar $=0.1 \mathrm{~cm}$. (F) Last cell built with the prey and the egg placed on it. $S c a l e ~ b a r=0.5 \mathrm{~cm}$. 


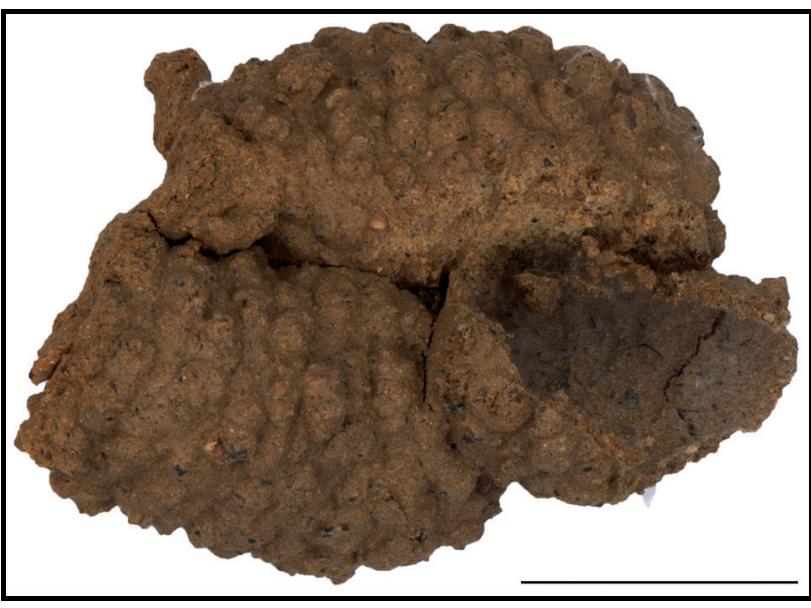

Figure 4. Nest of Auplopus cf. brasiliensis. The third cell broke during handling. Note the arrangement of the cells forming a cluster, the papillated surface suggesting the employment of several mud pellets to construct the cells. Scale bar $=0.5 \mathrm{~cm}$.

\section{Auplopus cf. brasiliensis}

Only one nest of this species was collected in July/2017 (Table 1). This species was the only Hymenoptera species to build its nest in a hose trap. The nest had three brood cells: two of them were attacked by the parasitoid wasp Chaenotetratischus neotropicalis Marinho et al., 2019 (Eulophidae) and the third cell had a male specimen (Tables 1 and 2). One cell was opened (the broken cell in Fig. 4; the same brood cell is displayed in Marinho et al. (2019), Figs. 14-15, with the cocoon of the host full of several parasitoid pupae). The parasitoids were found inside the thick whitish cocoon, suggesting that they attacked the hosts right after it spun the cocoon and pupated. No specimens emerged from the second parasitized cell. This cell was opened after the first two specimens emerged; the specimens inside were also identified as C. neotropicalis. Due to the small size and fragile complexion, all of them were dried by the time the cell was opened.

The brood cells were arranged horizontally to the substrate, two cells side by side on the trap's floor and one built on top of the first two cells (Fig. 4). The cell's surface was papillated and had a rough aspect, whereas the inner surface was smooth. The anterior part of the cell was truncated, conferring it a jug-shaped form. The measurements taken from this nest are shown in Table 3.

\section{DISCUSSION}

Auplopus cf. rufipes and A. cf. brasiliensis are two species with no previous data on their natural history. Based on their emergence pattern, $A$. cf. rufipes is multivoltine and its nesting activity occurs from May to November. No pattern of nesting could be inferred for $A$. cf. brasiliensis, since only one nest was caught. The multivoltinism in the genus Auplopus was already observed for other species by Zanette et al. (2004) for A. militaris (Lynch-Arribalzaga) and by Buschini et al. (2007) for five unidentified species of Auplopus, with evidence that those species are multi- voltine with at least three generations per year, a pattern that matched the observed for $A$. cf. rufipes in this study.

Shimizu et al. (2010) correlated nesting behaviour with the development of some degree of sociality, reaching parasociality in some species of the tribe Ageniellini. Auplopus cf. rufipes seems to be a solitary species. Nest architecture, however, indicates apomorphic behaviour, according with Shimizu et al. (2010), which consider soil nesting the ancestral condition in Ageniellini and plastering soil with regurgitated water, a derived condition. Particularly in this case, females always built the nests by themselves. Also, extending and contracting their abdomen when an unwelcome observer approaches may be seen as a defensive or aggressive posture, suggesting lack of communal nesting, as observed by other authors for Ageniellini (Wcislo et al., 1988; Dos Santos et al., 2017). Nevertheless, communality can be present even when such aggressive behaviour exists, and the imbalance of maintaining this behaviour is thought to be on other traits, such as nest protection (Wcislo et al., 1988). The lack of a resolved phylogeny for this tribe, however, hinders placing these behaviours on an evolutionary perspective.

Based on field observations, A. cf. rufipes follows the general nest-construction pattern observed for other Auplopus species: building the cell, provisioning, oviposition, closing the cell, repeating the process all over until nest construction is finished (Evans, 1953). Auplopus cf. rufipes left its nests unattended for several hours, and for many occasions one unfinished cell was seen open and empty. The "lip" that these cells had before oviposition is probably used for cell closure right after it stores the prey and oviposits, adding water from its crop to reshape this lip-like structure into an operculum, as observed on the cell of $A$. semialatus Dreisbach (Wcislo et al., 1988). It could be hypothesised that this lip-shaped structure may be a defence against parasites, eliminating the need for the female to leave the nest unattended during the process of closing brood cells. Nest parasites usually succeed at oviposition when the female is away to search for materials for cell closure after provisioning. Since females of Auplopus species are able to carry water in the crop, this pre-made lip-shaped structure allows the wasp to seal the nest without getting away from it.

Regarding egg-laying behaviour, $A$. cf. rufipes differed from those species of Pompilidae, for which the position of the egg laid in the prey is documented. Two closely related species of Anoplius studied by Evans (1953), An. apiculatus atumnalis (Banks) and An. semirufus (Cresson) oviposit and place the egg in rather different ways from one another upon their prey. Since great variation is observed on the exact spot where the egg is laid in the spider among Pompilidae species, this character may be species specific (Evans, 1953; Evans \& Matthews, 1973). The larval feeding behaviour of $A$. cf. rufipes suggests a strong pumping musculature, similar to other Pepsinae larvae (Evans, 1959) that feed by sucking the fluid contents of the stocked prey. After development of the head capsule and mandibles, the larva may consume all that is left of the prey and pupate. Interestingly, 
A. cf. rufipes has a naked pupa, similar to the pompilid Ageniella flavipennis (Dos Santos et al., 2017), whereas A. cf. brasiliensis spun a whitish cocoon. These observations show that cocoon spinning varies across the Ageniellini (Evans \& Matthews, 1973; Krombein, 1991; Pham, 2016).

Although some aspects of the nest are alike among species of Auplopus, such as using mud pellets to build brood cells, nest architecture varies greatly throughout this genus. Barthélémy \& Pitts (2012) stated that Auplopus builds nests perpendicularly to the substrate where they stand, which is observed for several species of the group; on the other hand, $A$. cf. rufipes and $A$. cf. brasiliensis made nests parallel to the substrate as usual for other Neotropical species (Zanette et al., 2004; Buschini et al., 2007); however $A$. cf. rufipes, made leant cells which differ from the species studied in the aforementioned studies. This latter species oriented its cells similar to $A$. militaris (Lych-Arribalzaga), however the arrangement was different: they formed a bunch of stacked cells, occupying the cavity's full height, instead of a linear arrangement. Also, cell orientation differed markedly from those reported by Zanette et al. (2004), of which brood cells faced the bottom of the trap. The different arrangements between species may be driven by space or protection of inner cells from parasites, since females are usually reared from the innermost brood cells (Buschini et al., 2007). The mud layer over some brood cells are an additional protective barrier, blocking parasites from accessing to the inside of the cell. This, combined with stacking to occupy all of the cavity's height, may be a strategy to prevent parasitism in the innermost cells. However, despite the female's best efforts, parasitism still occurred.

Data concerning parasitism by Caenochrysis crotonis suggests its attack patterns depends on the type of prey stockpiled in the cells (spiders, in general), instead of the host itself (a specific spider species, for instance) (Obrecht \& Huber, 1993), since it occurs in nests of Trypoxylon (Crabronidae) (whose species store many small spiders per cell) and in other Pompilidae (whose species store a single spider per cell) (Perioto \& Lara, 2018). Regarding A. cf. brasiliensis, C. crotonis probably feeds on the larva after it pupates, since the parasitoids were observed developing inside the cocoon of $A$. cf. brasiliensis (Marinho et al., 2019), and no trace of the spider was observed in the cell. This record of parasitoidism contrasts with reports by Vidal (1996), which state that species of Chaenotetrastichus are cleptoparasites. The evidence gathered in this study shows that $C$. neotropicalis is a parasitoid. Other species of Chaenotetrastichus were recorded from nests of Auplopus (LaSalle, 1994) in North America, and perhaps species of this genus may be associated with other Auplopodina. However, scant records of Chaenotetrastichus hinder generalisation concerning this species interactions. The urban fragments where these two Auplopus species occur seem to be capable of harbouring parasites, which indicates good environmental quality (Sheffield et al., 2013).

The genus Auplopus, as most Auplopodina, is known to cut off most or all legs from its prey (Shimizu et al.,
2010; Kurczewski et al., 2017). Evans (1953) stated that feeding from the exuding haemolymph from the stumps was the original reason for the leg-cutting behaviour, and a pre-adaptation for better fitting of the prey into brood cells, and, further, for prey transportation. However, A. cf. rufipes can only feed from the stumps since only the last pair of legs of the preys was amputated. Furthermore, Shimizu et al. (2010) also recorded another Ageniellini species, Macromeris honesta (Smith), carrying a prey with the legs intact, as it was observed in other species of the tribe. The female of $M$. honesta performed various short flights carrying the spider by the spinnerets with their mandibles. This contrasts with other records for Ageniellini that amputate prey's legs to facilitate transport to the nest (Zanette et al., 2004; Dos Santos et al., 2017) and may favour the hypothesis proposed by Evans (1953).

Few studies in the Neotropics identify prey captured by pompilids for nest provision (Martins, 1991; Zanette et al., 2004). And even in those, the number of observations is limited. At the JBRJ, only one nest was opened to assess prey for $A$. cf. rufipes, due to the low number of samples. While all cells were provisioned with Frigga cf. quintensis, a common spider typical of open environments, to our knowledge, ours is the first record of this spider genus as host of Auplopus. Usually, pompilid wasps prey upon female spiders which are larger and, hence, a plentiful source of food for the offspring (Kurczewski et al., 2017). Interestingly, our study found that males were also used to provision the brood cells. Concerning the species collected, one could assume that $A$. cf. rufipes is a specialist hunter. However, some Pompilid species may switch prey preferences due to shortage of a specific prey, and this can happen suddenly (Martins, 1991). Some advocate that pompilids specialise in spider guilds that occupy similar niches or share ecological traits (Evans, 1953; Martins, 1991; Rodriguez et al., 2016). Due to the preference for nesting in open areas, $A$. cf. rufipes might prey on spiders that dwell in open habitats and happen to be the most abundant by the time the nest was built. Overall, this aspect of its nesting biology remains inconclusive due to the low abundance of nests in the field.

\section{CONCLUSION}

Auplopus cf. rufipes nests in open areas, seems to be multivoltine, builds nests much like other Auplopus species and has a naked pupa. This species prey on Frigga cf. quintensis (Salticidae), which suggests specialization, though this must be studied more carefully. Nests were targeted by the cleptoparasite Caenochrysis crotonis. Auplopus cf. brasiliensis seems to be rare in the area. Larvae spin a pupa during its development (a trait that seems to vary in the Ageniellini) and were attacked by the hyperparasitoid Chaenotetrastichus neotropicalis. Both species are inserted in an urban environment and due to their nesting dynamic, conservation measures may be important to maintain these species in the arboretum of the Jardim Botânico do Rio de Janeiro. 


\section{ACKNOWLEDGMENTS}

We thank Cecilia Waichert for had worked a great length to figure out the species identification; Renner Batista for have determined the prey species; Eduardo Fernando dos Santos for helping with some references; Kelli dos Santos Ramos, Pedro Barrios-Souza, Valéria Cid Maia and the anonymous reviewers for valuable suggestions that improved greatly early drafts of this paper. We thank André Hoffmann for the English reviewing and Maria Lucia Texeira from the Jardim Botânico do Rio de Janeiro for facilitate our entrance in the study area. This research was funded in part by the Coordenação de Aperfeiçoamento de Pessoal de Nível Superior Brasil (CAPES) - Finance Code 001, by the Conselho Nacional de Desenvolvimento Científico e Tecnológico - CNPq through the scholarship granted to DM (proc. 121188/2017-8), and registered at Sistema Nacional de Gestão do Patrimônio Genético e do Conhecimento Tradicional Associado under the code A3BBA4F. We are also thankful to the Programa de Pós-Graduação em Ciências Biológicas (Zoologia) of the Museu Nacional/ Universidade Federal do Rio de Janeiro for structural support and to the Projeto de Informatização da Coleção Entomológica do Museu Nacional/UFRJ, SIBBR/CNPq (proc. 405588/2015-1) for allowing the use of the photographic equipment. This paper is part of the SIGMA project № 21565 MN/UFRJ and the contribution number 55 from the HYMN. MUSEU NACIONAL VIVE!!!!!!

\section{REFERENCES}

Aguiar, A.P.; Deans, A.R.; Engel, M.S.; Forshage, M.; Huber, J.T.; Jennings, J.T.; Johnson, N.F.; Lelej, A.S.; Longino, J.T.; Lohrmann, V.; Miko, I.; Ohl, M.; Rasmussen, C.; Taeger, A.\& Yu, D.S.K. 2013. Order Hymenoptera. Zootaxa, 3703: 51-62. D0I

Barthélémy, C. \& Pitts, J. 2012. Observations on the nesting behavior of two agenielline spider wasps (Hymenoptera, Pompilidae) in Hong Kong, China: Macromerella honesta (Smith) and an Auplopus species. Journal of Hymenoptera Research, 28: 13-35. D0I

Buschini, M.L.T.; Luz, V. \& Basilio, S. 2007. Comparative aspects of the biology of five Auplopus species (Hymenoptera; Pompilidae; Pepsinae) from Brazil. Journal of Zoological Systematics and Evolutionary Research, 45: 329-35.

Evans, H.E. 1953. Comparative ethology and the systematics of spider wasps. Systematic Zoology, 2(4): 155-72.

Evans, H.E. 1959. The Larvae of Pompilidae (Hymenoptera). Annals of the Entomological Society of America, 52(4): 430-44.

Evans, H.E. \& Matthews, R.W. 1973. Behavioural observations on some Australian spider wasps (Hymenoptera: Pompilidae). Transactions of the Royal Entomological Society of London, 125: 45-55.

Krombein, K.V. 1991. Biosystematic studies of Ceylonese wasps, XIX: natural history notes in several families (Hymenoptera: Eumenidae, Vespidae, Pompilidae and (rabronidae). Smithsonian Contributions to Zoology, 19: 1-41. DOI
Kurczewski, F.E.; Edwards, G.B. \& Pitts, J.P. 2017. Hosts, nesting behavior, and ecology of some North American spider wasps (Hymenoptera: Pompilidae), II. Southeastern Naturalist, 16: 1-82. D0I

LaSalle, J. 1994. North American genera of Tetrastichinae (Hymenoptera: Eulophidae). Journal of Natural History, 28(2): 109-236.

Marinho, D.; Costa, V. \& Vivallo, F. 2019. First record and new species of the parasitoid wasp Chaenotetrastichus Graham (Hymenoptera: Eulophidae) for the Neotropical region, with notes on its biology and a key for the species of the genus. Zootaxa, 4604: 359-68.

Martins, R.P. 1991. Nesting behavior and prey of Poecilopompilus algidus fervidus and Tachypompilus xanthopterus (Hymenoptera: Pompilidae). Journal of the Kansas Entomological Society, 64: 231-36.

Obrecht, E. \& Huber, C. 1993. Ducke type specimens and other Brazilian insect types in the Emílio A. Goeldi collection in the Natural History Museum Bern (Switzerland). An Annotated Catalogue. Jahrbuch des Naturhistorischen Museums Bern, 11: 163-84. http://antbase.org/ants/ publications/20434/20434.pdf.

Perioto, N.W. \& Lara, R.I.R. 2018. Nest description, new parasitoid associations and geographical range of Trypoxylon (Trypoxylon) florale Richards (Hymenoptera: Crabronidae). Revista Chilena de Entomologia, 44: 297-302. https://www.biotaxa.org/rce/article/view/40496/34507.

Pham, P.H. 2016. Nesting biology of a spider wasp Auplopus sp. (Hymenoptera: Pompilidae) in Vietnam. Punjab University Journal of Zoology, 31(1): 19-23.

Rodriguez, J.; Pitts, J.P.; Florez, J.A.; Bond, J.E. \& von Dohlen, C.D. 2016. Molecular phylogeny of Pompilinae (Hymenoptera: Pompilidae): evidence for rapid diversification and host shifts in spider wasps. Molecular Phylogenetics and Evolution, 94: 55-64.

Dos Santos, E.F.; Waichert, C. \& Scott S.C.P. 2017. Behavioural notes on the Neotropical parasocial spider wasp Ageniella (Lissagenia) flavipennis (Banks) (Hymenoptera: Pompilidae), with host association. Ecological Entomology, 42: 96-99. DOI

Sheffield, C.S.; Pindar, A.; Packer, L. \& Kevan, P.G. 2013. The potential of cleptoparasitic bees as indicator taxa for assessing bee communities. Apidologie, 44: 501-10. https://link.springer.com/article/10.1007/ s13592-013-0200-2.

Shimizu, A.; Wasbauer, M. \& Takami, Y. 2010. Phylogeny and the evolution of nesting behaviour in the tribe Ageniellini (Insecta: Hymenoptera: Pompilidae). Zoological Journal of the Linnean Society, 160: 88-117. D0I

Vidal, S. 1996. Redescription and first record from Europe of the North American species Chaenotetrastichus semiflavus Girault, 1917 (Hymenoptera, Chalcidoidea: Eulophidae). Entomofauna, 17: 149-152.

Waichert, C. \& Pitts, J.P. 2012. Addition to the distributional record of Ageniella (Neotumagenia) amazonica Fernández, 1998 (Hymenoptera: Pompilidae) and establishment of a Neotype. Psyche, 2012: 1-3. DOI

Waichert, C.; Rodriguez, J.; Wasbauer, M.; von Dohlen, C.D. \& Pitts, J.P. 2015. Molecular phylogeny and systematics of spider wasps (Hymenoptera: Pompilidae): redefining subfamily boundaries and the origin of the family. Zoological Journal of the Linnean Society, 175: 271-87. D0I

Wcislo, W.T.; West-Eberhard, M.J. \& Eberhard, W.G. 1988. Natural history and behavior of a primitively social wasp, Auplopussemialatus, and its parasite, Irenangelus eberhardi (Hymenoptera: Pompilidae). Journal of Insect Behavior, 1: 247-60. https://repository.si.edu/handle/10088/18230.

Zanette, L.R.S.; Soares, L.A.; Pimenta, H.C.; Gonçalves, A.M. \& Martins, R.P. 2004. Nesting biology and sex ratios of Auplopus militaris (LynchArribalzaga, 1873) (Hymenoptera Pompilidae). Tropical Zoology, 17: $145-54$. 